\title{
Effect of Seed Treatment on Germination and Seedling Growth of Jamun (Syzygium cuminii L.)
}

\author{
Harish Patil $^{1 *}$, R.V. Tank ${ }^{1}$, Parvathi Bennurmath ${ }^{2}$ and Manoli Patel ${ }^{1}$ \\ ${ }^{1}$ Department of Fruit Science, ASPEE College of Horticulture and Forestry, Navsari \\ Agricultural University, Navsari-396 450, Gujarat, India \\ ${ }^{2}$ Department of Floriculture and Landscape Architecture, ASPEE College of Horticulture and \\ Forestry, Navsari Agricultural University, Navsari-396 450, Gujarat, India \\ *Corresponding author
}

\section{A B S T R A C T}

\begin{tabular}{|l|}
\hline Ke y w o r d s \\
$\begin{array}{l}\text { Jamun, Seed } \\
\text { treatment, } \\
\text { Germination, } \\
\text { Seedling growth }\end{array}$ \\
\hline Article Info \\
\hline $\begin{array}{l}\text { Accepted: } \\
\text { 24 January 2018 } \\
\text { Available Online: } \\
\text { 10 February } 2018\end{array}$ \\
\hline
\end{tabular}

\section{Introduction}

Jamun (Syzygium cuminii L.) is an important, under-exploited, indigenous fruit crop of our country. In India many tropical fruit tree species, most of which are not commercially cultivated, are highly popular as they not only provide a significant source of livelihood support to the rural people but also has a cultural and social value. Such underutilized fruits have been long sustained due to their importance for their nutritional value and as a source of rural and tribal household income. Jamun is one of such underutilized fruit species of great importance in India. The fruits are good sources of iron, minerals, sugars and proteins.

Jamun is commercially propagated by seeds for taking the advantage of nucellar embryony. Presently it is also being propagated by vegetative means viz., grafting and budding. To carryout propagation by vegetative methods, raising of healthy and vigorous seedling/rootstock is very important. Jamun seeds lose its viability quickly; hence it should be sown immediately after extraction. Several efforts were put forth for enhancing 
germination by use of chemicals and growth regulators like gibberlic acid, thiourea, $\mathrm{KNO}_{3}$,etc. besides soaking in water with varied success (Shanmugavelu, 1970). With these objectives of to observe the effect of seed treatment on germination and seedling growth of jamun, the present study was planned.

\section{Materials and Methods}

The experiment was conducted at Regional Horticultural Research Station, ASPEE College of Horticulture and Forestry, Navsari Agricultural University, Navsari during 20162017. Seeds required for the experiment were extracted from the disease free fully ripened fruits of jamun cv. Local by washing with water.

The freshly extracted seeds were subjected to six treatments viz. control $\left(\mathrm{S}_{1}\right)$, water soaking for $24 \mathrm{hrs}\left(\mathrm{S}_{2}\right)$, hot water $\left(100{ }^{0} \mathrm{C}\right)$ for $5 \mathrm{sec}$ $\left(\mathrm{S}_{3}\right), \mathrm{GA}_{3} @ 200 \mathrm{mg} \mathrm{l}^{-1}$ for $10 \mathrm{~min}\left(\mathrm{~S}_{4}\right), \mathrm{KNO}_{3}$ @ $0.5 \%$ for $10 \mathrm{~min}\left(\mathrm{~S}_{5}\right)$ and thiourea @ $0.5 \%$ for $10 \mathrm{~min}\left(\mathrm{~S}_{6}\right)$ repeated three times in completely randomised block design.

Seeds were sown during last week of June in polythene bags of size 9" x 7" filled with potting mixture. Watering was done immediately after sowing and at regular intervals. Observations on days for initiation of germination, germination per cent, number of leaves, seedling height $(\mathrm{cm})$ and stem diameter $(\mathrm{mm})$ were recorded.

The germination percentage was computed using the formula as bellow. The data generated from studies were subjected to analysis by using standard method suggested by Panse and Sukhatme (1967).

Total number of seed germinated Seed germination $\%=$ $\mathrm{x} 100$

Total number of seed sown

\section{Results and Discussion}

\section{Germination attributes}

The minimum days for initiation of germination (7.13 days) and maximum total germination percentage $(95.73 \%)$ were recorded (Table 1) in seed treatment water soaking for $24 \mathrm{hrs}\left(\mathrm{S}_{2}\right)$ whereas, maximum days for initiation of germination (10.60 days) and minimum total germination percentage $(80.93 \%)$ were recorded in control $\left(\mathrm{S}_{1}\right)$.

This might be due to the soaking the seeds in water at room temperature helps in softening the seed coats, removal of inhibitors and reduces the time required for germination and increases germination percentage (Hartman and Kester, 1997). The other possible fact for better germination percent by water soaking may be that it stimulates series of biochemical change in the seed that are essential to initiate the emergence process like break down dormancy, hydrolysis, metabolism of growth inhibitors, imbibitions, activation of enzymes (Ajouri et al., 2004). With respect to days for initiation of germination soaking of seeds in water stimulates and produces enzymes like amylase and lipase which activate storage materials in seeds. Rehydration causes early emergence due to the fact that all pregerminative processes for germination had already occurred in seed. The similar results were coincide with the findings of Swamy et al., (1999) in jamun and Pandey and Singh (2000) in guava.

\section{Shoot parameters}

\section{Seedling height}

The maximum seedling height of 22.30 and $41.37 \mathrm{~cm}$ was recorded (Table 1) in seedlings raised from seeds treated with $\mathrm{GA}_{3}$ @ $200 \mathrm{mg}$ $1^{-1}$ for $10 \mathrm{~min}\left(\mathrm{~S}_{4}\right)$ at 30 and 60 days of seed sowing as compared to other treatments. 
Table.1 Effect of seed treatment on germination and seedling growth of jamun

\begin{tabular}{|c|c|c|c|c|c|c|c|c|}
\hline \multirow[t]{2}{*}{ Treatments } & \multirow{2}{*}{$\begin{array}{c}\text { Days for } \\
\text { initiation of } \\
\text { germination }\end{array}$} & \multirow[t]{2}{*}{$\begin{array}{l}\text { Germination } \\
\text { per cent }(\%)\end{array}$} & \multicolumn{2}{|c|}{$\begin{array}{l}\text { Seedling height } \\
(\mathrm{cm})\end{array}$} & \multicolumn{2}{|c|}{ Number of leaves } & \multicolumn{2}{|c|}{$\begin{array}{c}\text { Stem diameter } \\
(\mathbf{m m})\end{array}$} \\
\hline & & & 30 DAS & 60 DAS & 30 DAS & 60 DAS & 30 DAS & 60 DAS \\
\hline$S_{1}-$ control & 10.60 & 80.93 & 16.67 & 27.43 & 6.40 & 13.40 & 1.86 & 2.73 \\
\hline $\mathrm{S}_{2}$ - Water soaking for $24 \mathrm{hrs}$ & 7.13 & 95.73 & 19.63 & 35.07 & 8.80 & 20.73 & 2.07 & 3.57 \\
\hline $\mathrm{S}_{3}$ - Hot water $100{ }^{0} \mathrm{C}$ for $5 \mathrm{sec}$ & 8.87 & 91.27 & 19.40 & 34.07 & 8.00 & 20.60 & 2.01 & 3.31 \\
\hline $\mathrm{S}_{4}-\mathbf{G A}_{3} @ 200 \mathrm{mg} \mathrm{l}^{-1}$ for $10 \mathrm{~min}$ & 7.47 & 94.93 & 22.30 & 41.37 & 10.40 & 25.40 & 2.34 & 3.86 \\
\hline $\mathrm{S}_{5}-\mathrm{KNO}_{3} @ 0.5 \%$ for $10 \mathrm{~min}$ & 8.47 & 91.00 & 21.20 & 38.03 & 10.00 & 22.93 & 2.24 & 3.75 \\
\hline S6-Thiourea@0.5\% for 10 min & 8.87 & 87.55 & 20.53 & 37.70 & 9.47 & 22.07 & 2.16 & 3.75 \\
\hline S.Em. \pm & 0.28 & 1.89 & 0.71 & 1.00 & 0.29 & 0.80 & 0.04 & 0.06 \\
\hline C.D. at $5 \%$ & 0.87 & 5.83 & 2.18 & 3.07 & 0.89 & 2.46 & 0.12 & 0.20 \\
\hline $\mathrm{CV} \%$ & 5.69 & 3.63 & 6.14 & 4.85 & 5.64 & 6.62 & 3.28 & 3.21 \\
\hline
\end{tabular}


The increased in seedling height with $\mathrm{GA}_{3}$ treatment was due to the fact that this hormone increased osmotic uptake of nutrients, causing cell multiplication and cell elongation in the cambium tissue of the intermodal region and thus increased height of the plant (Shanmugavelu, 1966). The results are also in accordance with result of Harshavardhan and Rajasekhar (2012) in jackfruit and Vasantha et al., (2014) in tamarind.

\section{Number of leaves per seedling}

Among the different seed treatment chemicals, jamun seeds treated with $\mathrm{GA}_{3} @$ $200 \mathrm{mg} \mathrm{l}^{-1}$ for $10 \mathrm{~min}\left(\mathrm{~S}_{4}\right)$ gave maximum number of leaves per seedling (10.40 and 25.40) as compared to other treatments at 30 and 60 days of seed sowing (Table 1).

It might be due to activity of $\mathrm{GA}_{3}$ at the apical meristem resulting in more synthesis of nucleoprotein responsible for increasing leaf initiation and area (Sen and Ghunti, 1976). It may be also due to $\mathrm{GA}_{3}$ which induced vigorous growth by more number of branches which in turn facilitates better harvest of sunshine by the plants to produce more number of leaves. This is in line with the results of Shaban (2010) in mango and Anjanaw et al., (2013) in papaya.

\section{Stem diameter}

Regarding the effect of seed treatment on stem diameter of jamun seedling, $\mathrm{GA}_{3}$ @ 200 $\mathrm{mg} \mathrm{l}^{-1}$ for $10 \mathrm{~min}\left(\mathrm{~S}_{4}\right)$ resulted in maximum stem diameter $(2.34$ and $3.86 \mathrm{~mm})$ at 30 and 60 days of seed sowing as compared to other treatments (Table 1). It might be due to greater cell division and elongation at the stem portion (Sen et al., 1990). It also might be due to increased photosynthetic activity, accelerated translocation and efficiency of utilising photosynthetic products resulting in cell elongation and rapid cell division in growing portion (Sargent, 1965).

\section{References}

Ajouri, A.; Asgedom S. and Becker. M. (2004). Seed priming enhances germination and seedling growth of barley under conditions of $\mathrm{P}$ and $\mathrm{Zn}$ deficiency. J. Pl. Nutri. Soil Sci. 16(2): 630-636.

Anjanaw, S. R.; Kanpure, R. N.; Kachouli, B. K. and Mandloi, D. S. (2013). Effect of plant growth regulators and growth media on seed germination and growth vigour of papaya. Ann. Plant Soil Res., 15(1): 31-34.

Harshavardhan, A. and Rajasekhar, M. (2012). Effect of pre-sowing seed treatments on seedling growth of jackfruit (Artocarpus heterophyllus Lam.). J. Res. ANGRAU. 40(4): 87-89.

Hartmann, H. T. and Kester, E. (1997). Plant propagation principles and practices. Prentice Hall of India Private Limited, New Delhi- 110001.

Pandey, D. and Singh. H. P. (2000). Effect of seed pre-treatment on promotion of germination in guava. Ann. Agric. Res., 21: 279-281.

Panse, V. G. and Sukhatme, P. V. (1967). "Statistical Methods for Agricultural Workers". ICAR, New Delhi.

Sargent, J. A. (1965). The penetration of growth regulators into leaves. Ann. Rev. Pl. Physiol., 16: 1-12.

Sen, S. K. and Ghunti, P. (1976). Effect of pre-sowing seed treatment on the germination and seedling growth in papaya. Orissa J. Hort., 4: 38-43.

Sen, S. K.; Hore, I. K. and Bandhopadhyay, A. (1990). Pre-sowing seed treatment and it's role in germination, seedlings growth and longevity of papaya. Orissa J. Agril. Res., 2(3-4): 160-164. 
Shaban, A. E. A. (2010). Improving seed germination and seedling growth of some mango rootstocks. AmericanEurasian J. Agric. \& Environ. Sci., 7(5): 535-541.

Shanmugavelu, K. G. (1966). Studies on the effect of plant growth regulator on the seedling of some tree plant species. South Indian Hort., 14: 24-25.

Shanmugavelu, K. R. (1970). Effect of gibberlic acid on seed germination and development of seedlings of some tree plant species. Madras Agric., 157: 311314.
Swamy, G. S. K.; Patil, P. B.; Athani, S. I. and Prabhushankar, D. S. (1999). Effect of organic and inorganic substances on germination of jamun (Syzygium cuminii L.) seeds. Advances in Agric. Res. in India, 11: 89-91.

Vasantha, P. T.; Vijendrakumar, R. C.; Guruprasad, T. R.; Hanumanthaiah, M. R. and Muttappanavr, R. D. (2014). Studies on influence of growth regulators and nutrient foliar spray on seedling growth of tamarind (Tamarindus indica L.). Asian $J$. Hort., 9(1): 206-209.

\section{How to cite this article:}

Harish Patil, R.V. Tank, Parvathi Bennurmath and Manoli Patel. 2018. Effect of Seed Treatment on Germination and Seedling Growth of Jamun (Syzygium cuminii L.). Int.J.Curr.Microbiol.App.Sci. 7(02): 2654-2659. doi: https://doi.org/10.20546/ijcmas.2018.702.322 